\title{
The Golgi Apparatus in the Glandular Cells of the Submaxillary Giland of the Adult Albino Rat.
}

\author{
By \\ Rikita Honda. \\ Department of Anatomy, University of Colorado School of Medicine, \\ Denver, Colorado, U. S. A. \\ Three plates (X-XII).

\section{Introduction.}

The Golgi apparatus and mitochondria have been reported as constant components of all the different types of animal cells and it is also claimed by many investigators that they are concerned in the secretory activity of the glandular cells. In his paper ('27) the author described the mitochondria in the submaxillary gland of the adult albino rat. A further study of the Golgi apparatus in this gland was suggested by Professor Ivan E. Wallin of the University of Colorado and the results of this study are given in the present paper.

\section{Historical.}

Before Golgi's studies, the existence of the reticular substance in the gland cells of the submaxillary gland of some animals had been observed and designated by different names, as ,, Gerüst “, , Netz “, ,, Retikularsubstanz " and ,, Zellsubstanznetz “, etc., by such investigators as Ebner ('72), Klein (79b), Langley ('84), Schief ferdecker ('84b), List ('86) and Stöhr ('87a).

On the other hand, Hoyer ('90) and Rawitz ('94) claimed that the reticular substance in the mucous cell of the submaxillary gland is an artificial product produced by the reagents. 
After Golgi ('98) gave a detailed description of the cell inclusion and designated them as the "apparato reticolare interno" which bears his name, the reticular substance in the cells of the submaxillary gland was reported as the Golgi apparatus or Golgi bodies by Bergen ('04), Kolster ('13), Cajal ('14), Bowen ('26) and others.

\section{Material and Method.}

The material was prepared as fresh as possible in such a manner that the submaxillary gland aind the so-called retrolingual gland of Ranvier were removed under the ether anesthesia, without killing the animal. Small pieces of the material were fixed by the osmic method of Sjövall, Kolatchev, Kopsch, Mann-Kopsch, with its modification of Ludford ('25), and also fixed by both the formol and alcohol silver nitrate methods of Cajal and Da Fano. These methods are detailed in Lee's "Vade-xnecum", and also in a number of text books to which the reader is referred.

In certain cases the animals were injected with atropin $0.01 \mathrm{gm}$. or pilocarpin $0.02 \mathrm{gm}$. Three hours after the injection, the glands were removed and fixed in the same manner as mentioned earlier.

All the slides prepared by the osomic methods were treated with turpentine to differentiate the Golgi bodies from the fat and lipoid granules and some of these slides were stained also with the mitochondrial methods of Altmann-Kull, Bensley, or Cowdry.

The cytoplasmic inclusions of the cell obtained by the silver methods and osmic methods for the Golgi apparatus have been claimed to be identical in the nerve cell, by Kopsch ('02) and in some somatic cells by his pupils, but according to the author's present investigations, the results of the osmic method of Kopsch, Mann-Kopsch and its modification of Ludford ('25), proved somewhat different from that of the silver methods of Cajal and Da Fano. In the epithelium of the small duct, the osmophile granules preserved by the osmic method appeared similar to the argentophile granules obtained by the silver method (fig. 1, 2), howerer, in the serozymogen cell, the osmophile granules stained by the osmic acid were found abundantly at the periphery of the nucleus and along the cell nembrane and some, between the serozymogen granules (fig. 3), but in the silver method, the minute granules were produced around the serozymogen granules and the reticular granules were observed on the side of the nucleus, between the nucleus and cell basis and between the nucleus and the free surface of the cell (fig. 4). In the serous cell, the 
osmophile granules were found around the nucleus and along the interand intracellular canaliculi in form of rods or threads and a few forming a network (fig. 5). Preparation by the silver methods produced similar figures to those by the osmic methods, but careful observation showed that the granules of spiral form were preserved more abundantly by the silver method (fig. 6). In the mucous cell, the network, threads and rods were stained by the osmic acid along the nucleus and cell membrane (fig. 7), but in the silver method, different figures were produced; the granules were abundant in form of a network, threads, spirals and vacuoles (fig. 8), Hoyer ('90) and Rawitz ('94) claimed these granules to be artificial products. The author failed to obtain evidence for this view but is fully convinced that the figures obtained by the osmic and silver methods are not identical in all of the cells as claimed by Kopsch and his pupils. In further work, the author relied on preparations by the osmic methods since these have been more used in this field by recent investigators.

\section{Observations.}

Before reporting the details of the observations, a brief statement may be made on the classification of the cells of the submaxillary gland in the albino rat. In the previous paper ('27), four different types of cells were distinguished: the mucous, serous and the serozymogen cells together with the epithelial cells of the small ducts. In the albino rat the mucous cells are generally found in the retrolingual gland of Ranvier and in rare cases form islets in the submaxillary gland (Honda '27), consequently, the mucous cell was included to the above classification.

1. Epithelium of the small duct: In material treated by the osmic methods the cytoplasm of the typical cell of the small ducts was stained gray, the nucleus slightly lighter and the main-nucleolus and sidenucleoli were slightly stained but darker than surrounding nucleoplasm.

The Golgi apparatus stained black in the form of network, threads and small granules. The network was found mostly between the nucleus and the free surface of the cell but sometimes, at the side of the nucleus and in rare cases, between the nucleus and cell basis and part of the network had some connection to the nucleus. Some of the thread-like and granular forms were scattered in the cytoplasm but more abundantly in the infranuclear region and the osmophile granules were seen occasionally, in the secretory substance in the lumen (fig. 1).

In the gland, after atropin, the Golgi bodies were stained more 
clearly, which indicates an increase of materials or an affinity to the osmic acid, and the thread-like and granular forms increased in number and enlarged (fig. 9).

In the gland, after pilocarpin, the cells showed reverse effects. The Golgi bodies decreased in their staining affinity to the osmic acid and the thread-like and granular forms decreased in number and in size (fig. 10).

2. The serozymogen cell: The cytoplasm is slightly stained by the osmic acid method and the serozymogen granules are preserved in a spherical or oval form and stained a little darker than the surrounding cytoplasm. The nucleus stained lighter, as in the epithelium of the small duct and the main-nucleolus and side-nucleoli were stained slightly dark, like the serozymogen granules.

The Golgi bodies were stained black and preserved in irregular networks, spiral granules, coiled or short rods and twisted threads.

The reticular network was found mostly between the nucleus and the free surface of the cell, at the side of the nucleus, and in rare cases, between the nucleus and cell basis. Some filaments of the network were extended to the surrounding cytoplasm, rumning between the serozymogen granules. The granular forms also were found around the nucleus and along the cell membrane (fig. 3).

In the gland, after atropin, the Golgi bodies were scattered more irregularly between the serozymogen granules and were found more abundantly along the cell membrane, increased in number and enlarged (fig. 11).

In the gland, after pilocarpin, the cytoplasm appeared slightly more transparent than in the normal and the Golgi bodies decreased in number and in size (fig. 12).

3. The serous cell: The cytoplasm of the serous cell was stained gray while the so-called ergastoplasma stained comparatively dark. The nucleus stained a little darker than the surrounding cytoplasm and the main-nucleolus and side-nacleoli, a little darker than surrounding nucleoplasm.

The Golgi bodies were observed also, near the nucleus in form. of a network, spherical granules, short rods and twisted threads, around the nucleus and along intra and inter-cellular canaliculi (fig. 5).

In the gland, after atropin, the Golgi apparatus did not show a conspicuous change in comparison with the normal, except that the Golgi bodies were stained more distinctly by the osmic acid, increased in number and in part enlarged (fig. 13). 
In the gland, after pilocarpin, the cytoplasm of the cell was a little more transparent than in the normal and the Golgi bodies decreased in number and in size (fig. 14).

4. The mucous cell: The cytoplasm of the mucous cell was not stained by the osmic acid like other types of cells and appeared lighter in color.

The Golgi bodies were stained black with the osmic acid in form of small spherical granules, short rods, twisted threads and networks, especially around the nucleus and cell membrane (fig. 7).

In the gland, after atropin, the Golgi bodies were stained more distinctly, increased in number and enlarged (fig. 15).

In the gland, after pilocarpin, the appearance of the cells was the reverse of that after atropin and the Golgi bodies were not stained as distinctly as in the normal and were decreased in number and in size, some in the form of vacuoles (fig. 16).

\section{Singnificance of the Golgi Apparatus.}

a. Morphology. The Golgi apparatus shows a number of variations in the different types of cells and also, according to the cell activity. Even in the same cell types some differences have been observed according to the species of the animal. These facts gave rise to a number of designations for this organ until Golgi ('98) designated the granules as "apparato reticolare interno".

Bergen ('04) studied the Golgi apparatus in the serous and mucous cells of the submaxillary gland of the dog in the material fixed by Golgi's method modified by Veratti, and by the osmic method of Kopsch and observed the Golgi apparatus in form of granules, rods, twisted threads and networks. He classified two different types of granules, solid and canalicular; the former were preserved both by the osmic and silver methods; the latter were preserved only by the silver method, especially, in the mucous cell and he claimed that these granules resembled the ,, Primitivröhrchen " of Nansen ('87), ,, Trophospongien " of Holmgren ('02), "état spriémateux" of Nelis ('99), etc. He agreed with Van Beneden who claimed that these canalicular granules were artificially produced by the precipitation of the silver nitrate in the fluid substance in the cell.

The author also observed similar granules which had been claimed as artificial products by $\mathrm{T}$ an Benden, Hoyer, Rawitz and Bergen in materials fixed by the silver method of. Cajal and Da Fano, especially 
in the mucous cell (fig. 8), but not in the material fixed by the osmic method of Kopsch, Mamn-Kopsch and its modification of Ludford (fig. 7). The author does not regard these granules as artificial products because there is not sufficient evidence that these argentophile granules, which are brought out by the silver methods in the cells of the submaxillary gland, are artificial, however, it is possible that they belong to a fluid canalicular system, for similar granules-were observed on the slide with the mixture of saliva in the fixative fluid of Cajal or Da Fano.

Cajal ('14) studied the Golgi apparatus of the submaxillary gland of the rabbit, cat and young dog in material fixed by formol and by the alcohol uranium silver nitrate method and reported that the Golgi bodies were cbserved in the form of network, horseshoe and circular bands, between the nucleus and the glandular lumen and fragmentation of the apparatus was observed after pilocarpin.

Bowen ('26) reported that the Golgi apparatus in the submaxillary gland of Limax was observed in granular forms and scattered in the cytoplasm.

According to the author's investigation, the Golgi apparatus was observed in approximately two different morphological types as described by Nassonov ('24) and Bowen ('24) in the somatic cells; one in the form of network which has been designated by Bowen ('24) as the "Golgi complex" and the other in granular form known as " dictyosomes" (a term designating the solid elements of the Golgi apparatus when not in the reticular form in the spermatozoon). The network is present in most cells of the epithelium of the ducts, but not constantly in other types of cells.

In the submaxillary gland of the normal adult albino rat, as well as in the animals injected with atropin or pilocarpin, these granules are scattered in the cytoplasm and a few comnected to the nuclear wall.

b. Staining reactions. In staining it is very important to be able to distinguish the Golgi apparatus from that of the other cytoplasmic inclusions such as mitochondria, fat and lipoid granules. It has been maintained that the characteristic elements of the Golgi apparatus when stained black by the silver nitrate or osmic acid are distinguished easily from other granules. In the silver method of Cajal or Da Fano, the Golgi apparatus stains black; the fat, lipoid granules and mitochondria are, for the most part, not stained, except that the mitochondria sometimes show a slightly golden color. By the osmic method the Golgi apparatus, fat and lipoid granules are stained black, but the first is distinguished easily from the latter by the treatment with turpentine, as 
The Golgi Apparatus in the Glandular Cells of the Submaxillary Gland of etc. 209

the fat and lipoid granules lose their color more quickly than the Golgi apparatus while the mitochondria remain unstained.

According to the author's investigation, the silver methods of Cajal or Da Fano and the osmic method of Kopsch, Mann-Kopsch and its modification by Ludford, also preserved some mitochondria stained black, which are identical with the basophilic granules as claimed by the author in the previous paper $\left({ }^{\prime} 27\right)$. It is there pointed out that some mitochondria take the basic stain in the fixed material by the method of Kopsch after Regaud when stained by the Altmann-Kull method and the results are in accordance with those of Sjövall ('06), Nassonov ('23) and others and the Golgi apparatus is preserved by the osmic acid method used for mitochondria.

Similar observations touching the vital staining qualities of the (rolgi apparatus have been reported by Nussbaum ('13) and Karpova ('25), namely, that both the Golgi apparatus and mitochondria are stained in the spermatozoon by the mitochondrial vital staining methods. These facts led Karpova to claim that it was impossible to distinguish fundamentally the dictyosomes from the mitochondria and her opinion has been confirmed by Parat and Painlevé ('26). As mentioned earlier, the author finds that the staining qualities of the Golgi apparatus and the mitochondria are the same when stained by basic dyes, but on the other hand, the network of the Golgi apparatus does not show distinctly with the mitochondrial technique used by the author, owing to the presence of the mitochondria stained by the acid dye.

c. Position of the Golgi apparatus. Bergen ('04) claimed that the network of the Golgi apparatus was situated between the nucleus and the glandular lumen in the submaxillary gland of the $\operatorname{dog}$ and Cajal ('14) made the same observation in the submaxillary gland of the rabbit, cat and young dog. Cowdry ('21) found that Golgi apparatus was usually situated between the nucleus and the glandular lumen in the glandular cells of the thyroid gland of the guinea pig and in about one case out of five hundred the apparatus was situated between the nucleus and cell basis and he concluded that the position of the Golgi apparatus indicated the secretory polarity of the cell. Ludford ('22) also found that the Golgi apparatus was situated between the nucleus and free surface of the glandular cells. These topographic relations of the Golgi apparatus were reported by other investigators such as Courrier ('22) in the parathyroid gland of the young cat, Reiss ('22) in the hypophysis of the young cat, Corti ('24) in the gastric glands of the Rana esculenta, Jasswoin ('25) in the convoluted tubuli of the kidney of the Triton, 
Saguchi ('20) in the pancreas of the frog, Ishimaru ('26) in the thyroid gland of the rabbit.

Jacobs ('15) in the glandular cells of the intestines of the Astacus and Bowen ('26) in the submaxillary gland of the Limax, observed that the Golgi bodies were scattered in the form of granules in the cytoplasm.

Jasswoin ('25) found that in the convoluted tubuli of Triton, the Golgi apparatus changed its position passing from the supra-, para- and infranuclear region according to the functional stages.

The author observed the Golgi apparatus to appear in approximately two different types; one in the form of granules and the other in the form of a network. The former are scattered in the cytoplasm and the latter are observed in most cases to be supra- or paranuclear and in a few cases, in the infranuclear region. These topographic rclations of the network were found especially in the epithelium of the duct (fig. 1) of the submaxillary gland of the albino rat and correspond with Cowdry's observations on the thyroid gland of the guinea pig.

\section{The Genesis of the Golgi Apparatus.}

The genesis of the Golgi apparatus has been much studied but the problem still remains unsolved. The granular form is identical with the mitochondria which are preserved by Kopsch's method after Regaud and stained by the basic dye with the staining method of AltmannKull, which corresponds with the results of Karpova, in the spermatozoon of the Helix pomatia, and the dictyosomes appear to be modifications of mitochondria. But the genesis of the Golgi network (sometimes crescent-shaped or spiral), is apparently different from the former although the staining reactions do not indicate the difference. The latter is assumed to originate from the nucleus by the physiological degeneration of the cell.

For a study of the genesis of the network, the serozymogen cell proved to be the best and a brief description of the formation of the serozymogen granules is therefore necessary. Two different opinions are current on the genesis of the secretory granules, i. e., (1) the cytoplasmic or (2) the nuclear origin in the different glandular cells, especially in the pancreatic cell. The cytoplasmic origin has been maintained in the pancreatic cells by such investigators as R. Heidenhain ('80), Langley' ('84), Carlier ('96), Mouret ('95, '05), Laguesse ('99), Garnier ('00), Ma thews ('99), Altmann ('94), Michaelis ('00), Benda ('00) Bouin ('05), Regaud and Mawas ('09), Hoven ('10, '12), O. Schultze ('11), 
The Golgi Apparatus in the Glandular Cells of the Submaxillary Gland of ete. 211

Champy ('11), Arnold ('12), Maximow ('16), and others. The nuclear origin has been supported by Macallum ('91), Mathews ('99), Garnier ('00), Carlier ('99 '07), Maziarski ('10), Ogata ('83), Laguesse ('99, '00), Galeotti ('95), etc. However, most investigators have observed that there exist different kinds of secretory granules differentiated from each other by their staining reactions and have described these granules as "graugelb and fuchsinophile"; "osmophile and fuchsinophile"; "basophile, acidophile and neutrophile", etc., in the different types of glandular cells. The staining reactions do not, however, reveal the different origins of the granules. According to the author's investigation, there are two kinds of secretory granules in the submaxillary gland; those of cytoplasmic and those of nuclear origin. The former have been observed by various investigators and recently, Takagi ('25) demonstrated them with great clearness in the submaxillary gland of the cat. As also claimed by the author ('27), these originate from an integration or morphological changes of the mitochondria in the albino rat and have not been observed distinctly in the material fixed by the osmic methods for the Golgi apparatus. The latter originate by the physiological degeneration of the plasmosomes (Ogata), or main-nucleolus and sidenucleoli (Saguchi). The structure of the main-nucleolus and sidenucleoli has been described in detail in the pancreatic cell of the frog by Saguchi ('20), to which paper the reader is referred. Since then the author has observed that the nuclear inclusions in the cells of the submaxillary gland of the albino rat were similar in structure to those of the pancreatic cell of the frog. The nucleolus is composed of three different substances well distinguished from each other by the staining reactions and morphology in material fixed by various methods; the outer layer is well stained by the basic dye such as the Kopsch's method after Regaud and stained by the Altmann-Kull method like a capsule. This was, designated as " cortical substance" by Saguchi ('20), " argentophile core" by Cajal and Carleton ('20). The nucleolus contains one or more minute granules well preserved, especially by the silver methods, which were observed by Lache ('06) and Cajal ('09) and designated as "nucleolini", “endonucleoli" by Carlier ('96), "argentophile granules" by Saguchi ('20). The rest of the substance of the nucleolus is preserved and stained gray in color by the osmic methods and it is also well preserved by the various mitochondrial methods. For instance, it is stained by the acid fuchsin in the material fixed by the same method as for the cortical substance mentioned above and it was designated by Saguchi ('20) as the "main mass" of the nucleolus. Further study on these 
nuclear inclusion has been carried on by the author in the secretory cycle of the serozymogen cell connected with the genesis of the Golgi apparatus and the formation of the secretory granules. The whole process of the secretory cycle is classified by the author into four different stages instead of the two or thren which have been commonly used by most investigators, such as "functioning and resting stages", or " secreting, resting and excreting stages". In our material the serozymogen cell is observed to be clearly different in the four following stages: (1) absorbent or hyperchromatic stage, (2) granulation stage, (3) resting stage, (4) excretory stage.

(1) Absorbent or hyperchromatic stage. In this stage the size of the nucleus and cell body is relatively small in comparison with the other stages, probably due to the pressure of the adjoining cells whicn are in the different stages. In the beginning of this stage, the nucleus and cytoplasm appear comparatively transparent in the material fixed by the osmic methods, suggesting that the materials to be stained by the osmic acid are scanty (fig. A). The fact that some of the cells cells stain darker by the osmic acid indicates that more substance has been absorbed by the cytoplasm from the surrounding blood and lymph capillaries (fig. B), and the nucleus also becomes larger and gradually stains a darker color, especially in the nuclear wall while the cytoplasm around the nucleus appears light in color (fig. C), which reveales that substances from the cytoplasm are given to the nucleus. The nucleolus also is increased in size and stains darker (fig. D). This phenomenon is observed in most cases in the main-nucleolus and in some cases simultaneously, in the side-nucleoli, but in the majority of cases, the side-nucleoli follow after the main-nucleolus has arrived at the resting stage (fig. G), or the sidenucleoli remain without much change suggests that they are prepared for the succeeding secretory cycle. In some cases, the nucleolus is observed in a thickened area of the nuclear wall, or outside of the nucleus as the so-called "Nebenkern" (fig. E). The identity of the nucleolus and nebenkern is not as yet settled and a number of different opinions has been expressed as to its origin, morphology and significance, but the author has arrived to the conclusion that the so-called "Nebenkern" is nothing but a nucleolus arising from the nucleus and this conclusion is in accordance with those of Ogata ('83), Platner ('89), Galeotti ('95), in the pancreatic cell.

The Golgi apparatus ("Golgi complex" of Bowen) appears in irregular forms of network, crescent-shaped masses, spirals and branched threads and some of these granules are observed to be in contact with the suclear wall (fig. A, B, C, D, E). 
The Golgi Apparatus in the Glandular Cells of the submaxillary Giland of etc. 213

(2) Granulation stage. In this stage granulation occurs in the mainnucleolus (fig. F) and in a few cases, in the side nucleoli (fig. G, H) and continues until the gramulation stage of the cell is completed (fig. I, J).

The Golgi apparatus is situated in most cases, between the nucleus and glandular lumen, or at the side of the nucleus (fig. F. G) and appears in the form of a network, crescentshaped masses, spirals and branched threads. When the cell is being filled with serozymogen granules, the apparatus is pressed, gradually, toward the cell boundary and projections of the apparatus are obscrved between the serozymogen granules (fig. G, H). Strictly speaking, a definite morphology and position of the Golgi apparatus in this stage can hardly be given because the apparatus is influenced by the momentary changes of the formation of serozymogen granules.

(3) Resting stage. In this stage, the cell body is enlarged by the accumulation of the serozymogen granules and the nucleus is commonly situated on the cell basis with an irregular form due to the pressure of the granules (fig. K) and sometimes the cell body is so filled with the serozymogen granules that the nucleus is obscured (fig. $\mathrm{L}$ ).

The Golgi apparatus is situated irregulary along the cell membrane, rather more towards the distal end of the cell and between the nucleus and periphery of the cell (fig. K). In rare cases, it lies between the nucleus and cell basis.

(4) Excretory stage. The serozymogen granules become larger and lose their staining power with the osmic acid (fig. M) to such an extent that the granules do not take much stain, a condition which suggests a reciprocal exchange of substances between the granules and cytoplasm (fig. N).

The Golgi bodies become less in number and slender in appearance which assumes that they form a part of the secretion and are discharged as a secretory substance (fig. M, N). With the discharge of material the cell becomes smaller in size which change is probably, in part, due to the pressure of the adjoining cells in the different stages. The remaining Golgi bodies appear to come together and form a part of the nucleus (fig. O).

The author is fully convinced that the Golgi apparatus originates from the nucleus and is related to the formation of the serozymogen granules of the serozymogen cell. In other words, the Golgi apparatus is formed by the chromatic bodies of the nucleus discharged into the cytoplasm by the chromatolysis or physiological degeneration of the cell. My own observations apply to the physiological degeneration or chro- 
matolysis of the serozymogen cell of the submaxillary gland of the albino rat but in the pancreatic cells of other animals the process has been described by many investigators and Saguchi ('20) has reviewed and summarized the literature. Gaule ('80) and Nussbaum ('82) noticed that the pancreatic cell undergoes physiological degeneration which process has been detailed by Platuer ('89) and confirmed by Saguchi ('20) who briefly described the process as follows: "The first changes are in the chromatic and nuclear hyperchromasy, followed by chromatic separation. The latter process is characterized by a flowing together of chromatic corpuscles which leads to the formation of more or less large granules or thick cords. These further fuse together or anastomose with one another so that at last a network or even a capsule is formed at the periphery of the nucleus ".

The process in the serozymogen cell of the submaxillary gland of the rat appears to the author to be in accordance with that described for the pancreatic cell and he comes to the conclusion that the Golgi apparatus as shown by the osmic method is formed by chromatic bodies originated from the nucleus and discharged into the cytoplasm.

The author believes that the genesis of the Golgi apparatus in other types of cells in the submaxillary gland of the rat is similar to that in the serozymogen cell, even though the secretory cycle could not be clearly observed.

\section{Summary.}

1. The cytoplasmic inclusions of the glandular cells of the submaxillary gland of the adult albino rat obtained by the silver and osmic methods for the Golgi apparatus are not the same in the several types of cells and differ especially in the mucous cell.

2. The Golgi bodies in the glandular cells of the submaxillary gland are increased in number and enlarged when the animal is injected with atropin and decreased in number and size when it is injected with pilocarpin.

3. Morphologically, the Golgi apparatus of the submaxillary gland of the adult albino rat preserved by the osmic method shows two types: one in the form of a network, sometimes crescent-shape, spirals, etc., (Golgi complex of Bowen) and the other is in the form of granules (designated dictyosomes) which prove to be modifications of the mitochondria; a result that is in accordance with those of Karpova based on the vital staining method of the spermatozoon. 
The Golgi Ipparatus in the Glandular Cells of the Submaxillary Gland of ete. 215

4. Topographically, the network of the Golgi apparatus indicates the secretory polarity of the glandular cells of the submaxillary gland of the adult albino rat; an observation in accord with Cowdry's report for the cells of the thyroid gland of the guinea pig.

5. The network apparatus of Golgi (Golgi complex of Bowen) originates from the nucleus by the formation of the serozymogen granules and is represented by chromatic bodies produced by the chromatolysis or physiological degeneration of the serozymogen cell, a fact which holds true in other types of cells in the submaxillary gland of the adult albino rat.

\section{Literature Cited.}

Altmann, R. 1894 Die Flementarorganismen und ihre Beziehungen zu den Zellen, 2. Auflage. I.eipzig.

Arima, I. H. 1918 Über die paradoxe Speichelsekretion bei chronischer Itropinvergiftung. Arch. f. exper. Path. und Pharm., Bd. 83.

A rnold, (i. 1912 The rôle of chondriosomes in the cells of the guinea pig's pancreas. Irch. f. Zellforschung, Bd. 8.

Bergen, Von F. $1904 \mathrm{Zur}$ Kenntniss gewisser Strukturbilder (, Netzapparate “, „, Saftkanälichen", "Trophospongien") im Protoplasma verschiedener Zellenarten. Arch. f. mikr. Anat., Bd. 64.

Bowen, R. H. 1924 On a possible relation between the Golgi apparatus and secretory products. Amer. Jour. of Anat., vol. 33.

1926 Studies on the Golgi-Apparatus in Gland-Cells. I. Cilands associated with the Alimentary Tract. Quart. Journ. of Microscop. Science 70, 75-112.

Cajal, S. Ramon $1914 \Lambda$ lgunas variaciones fisiológicas y patológicas del aparato reticular de Golgi. Trabajos del laborat. de investig. biol. de la miv. de Madrid, vol. 12.

Carlier, E. W. 1896 On the pancreas of the hedgehog during hibernation. Jour. of Anat., vol. 30.

Cowdry, E. V. 1922 The reticular material as an indicator of phsiologic reversal in secretory polarity in the thyroid cells of the guinea pig. Amer. Jour. of Inat. 30 , pp. $25-37$.

Courrier, R. R. 1922 Contribution à l'histophysiologie du corps thyrö̈de. Compt. rend. des séances de la soc. de biol. 86, p. 869.

Courrier et Reiss, P. 1922 Appareil réticulé de Golgi et polarité sécrétoire des cellules parathyroïdiennes. Ditto. 86, p. 867.

Corti, A. 1924 Studi di morfologia cellulare. Lacunoma, Ipparato interno del Golgi, Trofospongio, Chondrioma, Idiosoma. Ric. d. morfol. 4, p. 313.

Champy, C. 1911 Recherches sur l'absorption intestinale et le rôle des mitochondries dans l'absorption et la sécrétion. Arch. d'anat. micr., T. 12.

Ebner, V. 1872 Über die Anfänge der Speichelgänge in den Alveolen der Speicheldrüsen. Arch. f. mikr. Anat., Bd. 8. s. 481. 
Galeotti, G. 1895 Über die Granulationen in den Zellen. Intern. Monatschr. f. Anat. u. Physiol., Bd. 12.

Garnier, C. 1900 Contribution à l'étude de la structure et du rôle de l'ergastoplasme dans la sécrétion. Journ. de l'Anat. et de la Physiol., 36 année.

Hoyer, H. 1890 Über den Nachweis des Mucins in Geweben mittelst der Färbemethode. Arch. f. mikr. Anat., Bd. 36, S. 310-374.

IIoven, H. 1910 Contribution à l'étude du fonctionnement des cellules glandulaires. Du rôle du chondriome dans la sécrétion. (Communication préliminaire). Anat. Anz., Bd. 37, No. 13, 14.

II onda, R. 1927 The general functional significance of the mitochondria in the submaxillary gland of the adult albino rat. Anat. Rec., v. 34, no. 5.

Ishimaru, S. 1926 Über den Golgi-Apparat in den Schilddrüsenzellen. Folia anat. Japon. 4, 13.

J a cobs, W. 1927 Der Golgi sche Binnenapparat. Frgebnisse und Probleme. Ergebnisse der Biologie, Bd. 2.

Jasswoin, (x. 1925 Zur IIistophysiologie der Tubuli contorti der Amphibienniere. Zeitschr. f. wiss. Biol., Abt. B: Zeitschr. f. Zellforsch. u. mikroskop. Anat. 2.

Karpova, J. 1925 Beobachtungen über den Apparat Golgi (Nebenkern) in den Samenzellen von Helix pomatia. Zeitschr. f. wiss. Biol., Abt., B : Zeitschr. f. Zellforsch. u. mikroskop. Anat. '2., S. 495-514.

Klein, E. $1879 \mathrm{~b}$ Observation on the structure of cells and nuclei. Quart. Jour. of Microsc. Sc. New Ser., vol. 19, pp. 125-175.

Kolster, R. 1913 Über die durch Golgi's Arsenik- und Cajal's Trannitrat Silbermethode darstellbaren Zellstructuren. Verh. d. anat. Gesch. Versainmlung XXVII.

I. a che, J. G. 1906 L'aspect du noyau de la cellule nerveuse dans la méthode à l'argent réduit. Anat. Anz., Bd. 28.

I.aguesse, E. 1899 Corpuscles paranucléaires (parasomes), filament basaux. et zymogène dans les cellules sécrétantes (pancréas, sous-maxillaire). Compt. rend. Soc. biol., Volume jubilaire.

Iangley, J. N. 1884 On the structure of secretory cells and on the changes which take place in them during secretion. Intern. Monatschr. f. Anat. u. Phpsiol., Bd. 1.

I,ist, T. II. 1886a Über Becherzellen und Leydigsche Zellen (Schleimzelln). Arch. f. mikrosk. Anat., Bd. 26. S. 543-55:.

Iöwonthal, N. 1894 Zur Kenntnis der Glandula submaxillaris einiger Säugetiere. Anat. Anz., Bd.. 9, \&. 223-229.

Iudford, R. J. 1925 Some modifications of the osmic acid methods in cytological technique. Journ. of the roy. microscop. soc., pp. 31-36.

M acallum, A. B. 1891 Contridution to the morphology and physiology of the cell. Transact. of the Canadian Institute, vol. 1 (quoted from Nathews and Eberth and Mïiller).

I athews, A. 1899 The changes in structure of the pancreas cells. A consideration of. some aspects of cell metabolism. Jour. Morph., vol. 15. supplement.

Naximow, A. 1916 Sur la structure des chondriosomes. Compt. rend. Soc. biol., T. 79.

Melissino, C. and Nicolaider, R. 1890 Untersuchungen über einige intra- und extranukleare Gebilde in Pankreas der Säugetiere und ihre Beziehung zu der Sekretion. Arch. f. Anat. u. Physiol. Abt., S. 317-325.

Michaelis, L. 1900 Die vitale Färbung, eine Darstellungsmethode der Zellgranula. Arch. f. mikr. Auat., Bd. is. 
The Golgi Apnaratus in the Glandular Cells of the Submaxillary Gland of etc. 217

Nassonov, D. N. 1923 Das Golgi sche Binnnennetz und seine Bezichung zu der Sekretion. Untersuchungen über einige $\Lambda$ mphibiendrüsen. Arch. f. mikr. Anat., 97, S. $137-180$.

1924 Das Golgi sche Bennennetz und seine Beziehung zur Sekretion (Fortset\%ung). Morphologische und experimentelle Untersuchungen an einigen Säugetierdrüsen. Ebenda 100, S. 433-469.

Nussbaum, J. 1913 U̇ber den sogenannten Golgischen Netzapparat und sein Verhältnis zu den Mitochondrien, Chromidien und anderen Zellstrukturen im Tierreich. Zusammenfassendes Sammelreferat. Arch. f. Zellforsch. 10, S. 357-367.

Ogata, M. 1883 Die Veränderung der Pankreaszellen bei der Sekretion. Arch. f. Anat. u. Physiol., Physiol., Abth.

Parat et Painlevé 1926 L'appareil de Golgi des cellules génitales mâles d'Helix et des autres pulmonés. Compt. rend. des séances de la soc. de biol. 94, p. 745.

Platner, G. 1889 Beiträge zur Kenntniss der Zelle und über ihre Teilung. Arch. f. mikr. Anat, Bd. 33.

Ranvier, I. A. 1886 Étude anatomiques des glandes connues sous les noms de sousmaxillaire et sublinguale, chez les mammifères. Arch. de Physiol. norm. et path., Ser. 3, T. 8, pp. 223-256.

Regaud and Mawas 1909 Ergastoplasme et mitochondries dans les cellules de la glande sous-maxillaire de l'homme. Compt. rend. Soc. biol., T. 66, pp. 461-463.

Reiss, P. 1922 L'appareil de Golgi dans les cellules glandulaires de l'hypophyse. Compt. rend. des séances de la soc. de biol. 87, p. 255.

Saguchi, S. 1920 Studies on the glandulat cells of the frog's pancreas. Amer. Jour. of Anat., vol. 25-26, pp. 347-407.

Schiefferdecker, P. 1884 Zur Kenntniss des Baues der Schleimdrüsen. Arch. f. mikr. Anat., Bd. 23, S. 382-412.

Schultze, O. 1911 Über den feineren Bau der Glandula submaxillaris des Menschen mit besonderer Berücksichtigung der Drüsengranula. Festschr. f. C. Gengenkaur., Leipzig, Bd. 2, S. 180-248.

Stöhr, Ph. 1887a Über Schleimdrüsen. Festschrift. A. v. Kölliker zur Feier seines 70. Geburtstages gewidmet von seinen Schülern. Leipzig. S. 423-444.

Sjövall, E. 1906 Ein Versuch, das Binnennetz von Golgi-Kopsch bei der Spermatound Orogenese zu homologisieren. Anat. Anz. 28, S. 561-578.

Ver Eecke, A. 1895 Modifications de la cellule pancreatique pendant l'activité sécrétoire. Arch. de Biol., T. 13.

Zumstein, J. J. 1891 Über die Unterkieferdrüse einiger Säuger. I. Anat. Teil. Habilitationsschrift. Marburg. 


\section{Explanation of Plates.}

All figures were outlined as far as possible with the aid of the camera lucida. The lenses used in Plate I and II were: Leitz 2-mm. apochr, oil-immer. obj., comp. ocular no. 8 and in Plate III the ocular no. 10 used.

\section{Plate $\mathrm{X}$.}

Fig. 1. The epithelium of the intralobular duct:

Fig. 3. The serozymogen acinus:

Fig. 5. The serous acinus: e, so-called ergastoplasma

Fig. 7. The mucous acinus: fixed: Mann-Kopsch's method, treated in turpentine for three hours, without stain.

Fig. 2. The epithelium of the intralobular duct:

Fig. 4. The serozymogen acinus:

Fig. 6. The serous acinus :

Fig. 8. The mucous acinus fixed: Da Fano's method, without stain.

\section{Plate XI.}

Fig. 9. The epithelium of the intralobular duct:

Fig. 11. The serozymogen acinus :

Fig. 13. The serous acinus :

Fig. 15. The mucous acinus: Material injected with atropin; fixed: Mann-Kopsch's method, without stain.

Fig. 10. The epithelium of the intralobular duct:

Fig. 12. The serozymogen acinus:

Fig. 14. The serous acinus:

Fig. 16. The mucous acinus: Material injected with pilocarpin; fixed: Mann-Kopsch's method, without stain.

\section{Plate XII.}

Fig. 1 g, Golgi apparatus; m, main-nucleolus; n, side-nucleoli ; d, so-called dictyosomes. Fig. A, B, C, D, E Absorbent or hypochromatic stage of the serozymogen cells:

Fig. F, G, H, I, J Granulation stage of the serozymogan cells:

Fig. K, I, Resting stage of the serozymogen cells :

Fig. II, N, O Excretory stage of the serozymogen cells: fixed: Mann-Kopsch's method, treated by turpentine for three hours, without stain. 


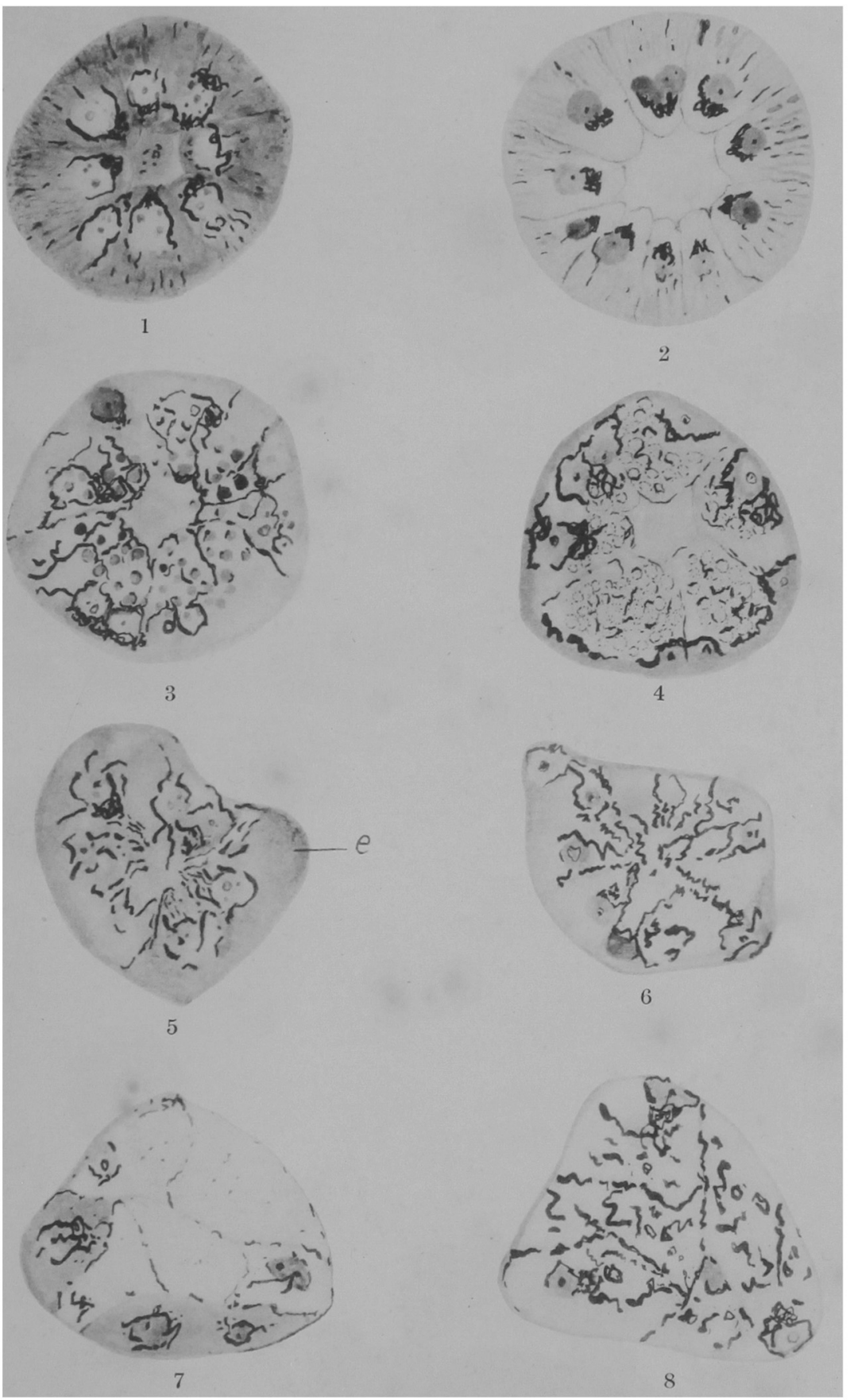

R. Honda. 


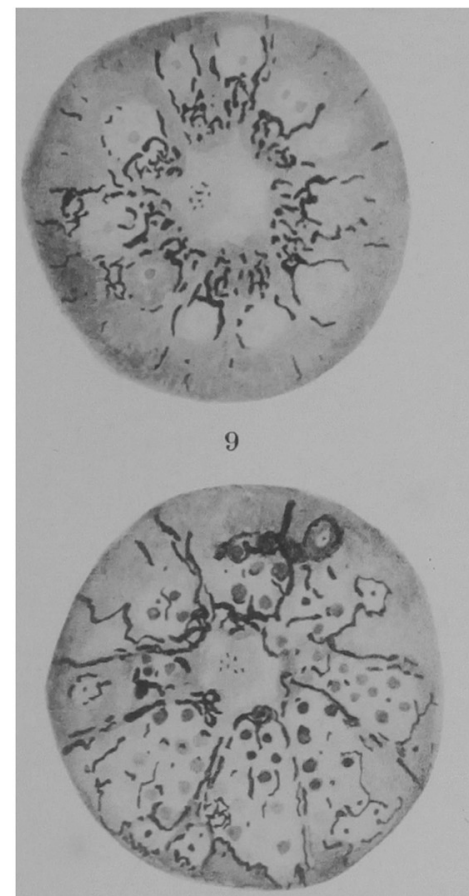

11

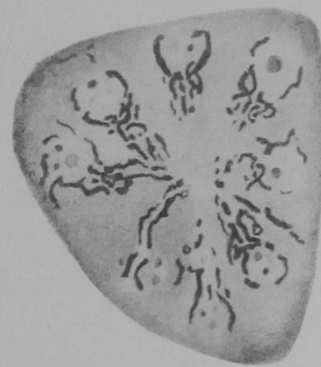

13

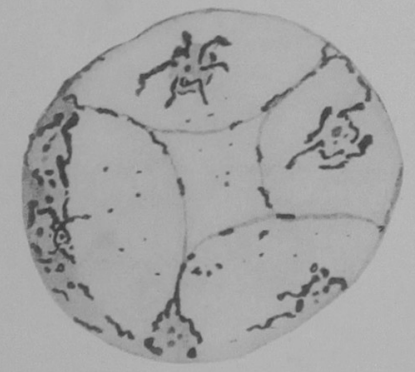

15

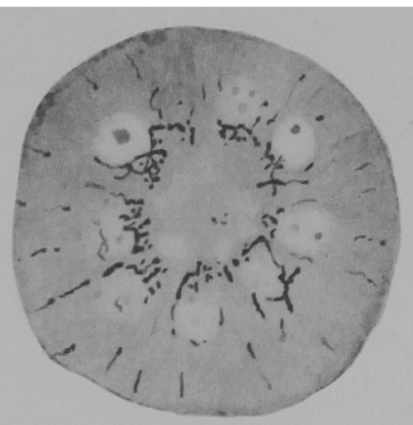

10

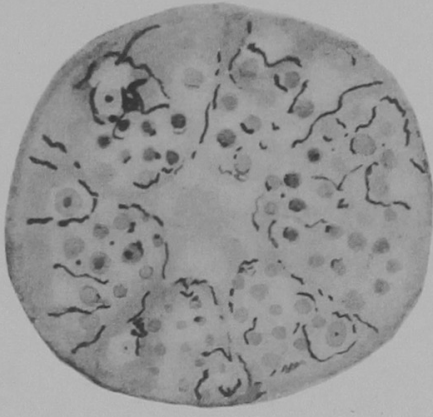

12

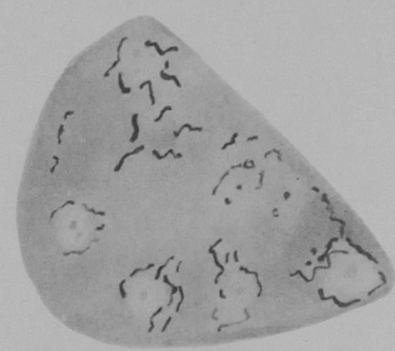

14

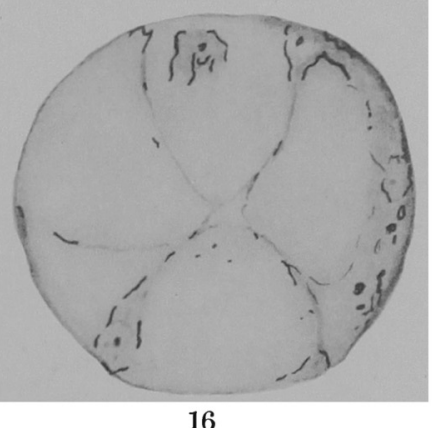

16

R. Honda. 

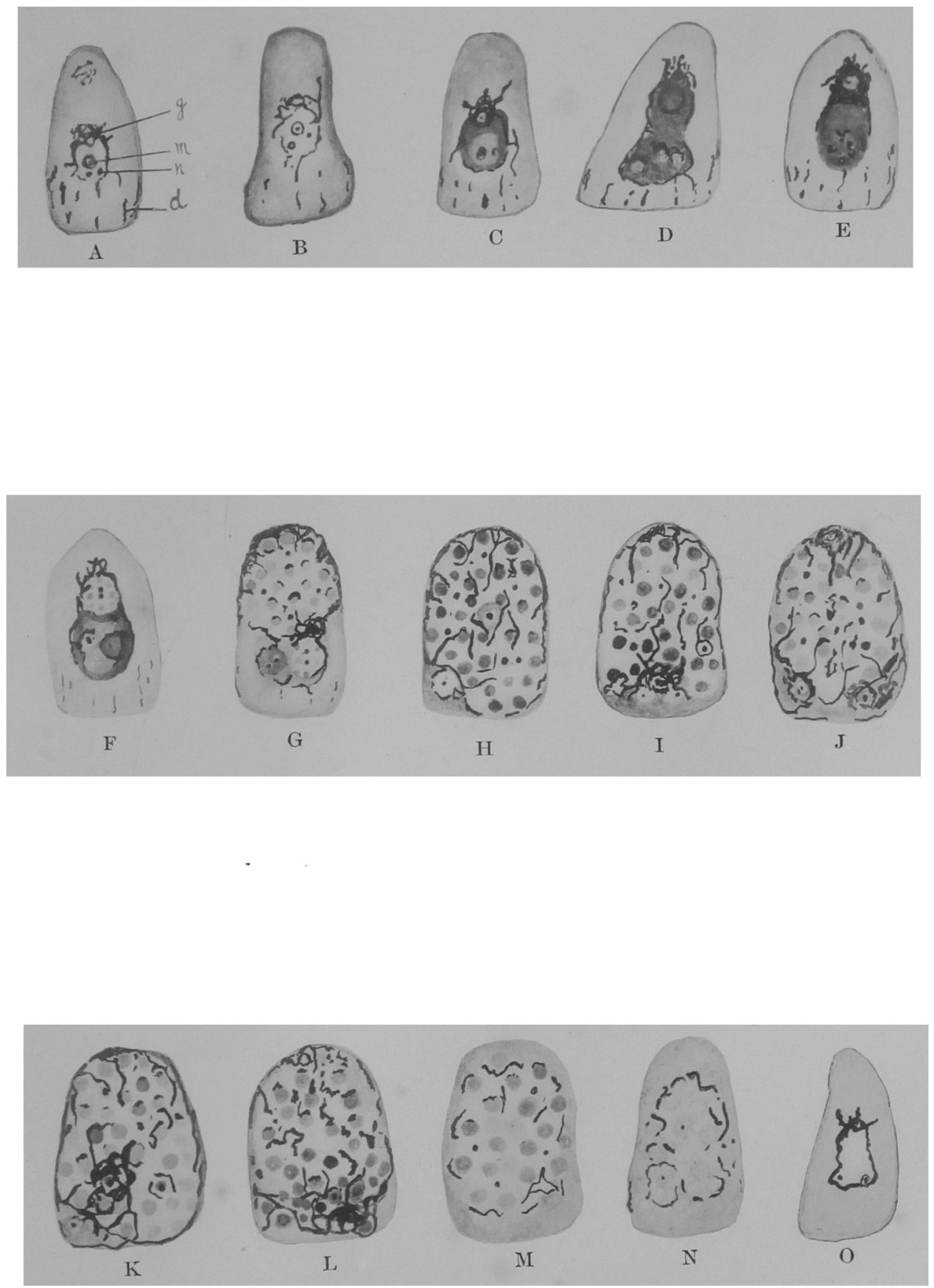

R. Honda. 